\title{
The KLIWAS North Sea Climatology. Part II: Assessment against Global Reanalyses
}

\author{
NILS H. SCHADE \\ Federal Maritime and Hydrographic Agency (BSH), and Centrum für Erdsystemforschung und Nachhaltigkeit, \\ Universität Hamburg, Hamburg, Germany \\ REMON SADIKNI, ANNIKA JAHNKE-BORNEMANN, AND IRIS HINRICHS \\ Centrum für Erdsystemforschung und Nachhaltigkeit, Universität Hamburg, Hamburg, Germany \\ LYDIA GATES AND BIRGER TINZ \\ Deutscher Wetterdienst (DWD), Hamburg, Germany \\ DETLEF STAMMER \\ Centrum für Erdsystemforschung und Nachhaltigkeit, Universität Hamburg, Hamburg, Germany
}

(Manuscript received 14 March 2017, in final form 14 September 2017)

\begin{abstract}
Observational reference datasets are needed in atmosphere and ocean for quality assessments of climate models and for the evaluation of atmospheric reanalyses. To meet this demand on the regional scale, the Climate Water Navigation (KLIWAS) North Sea climatology (KNSC) was developed. This paper uses KNSC to assess the quality of five atmospheric reanalysis products [ERA-40; ERA-Interim; NCEP-1; 20CR, version 2 (20CRv2); and MERRA] over the North Sea from 1979 to 2001. Differences in sea level pressure (2-m air temperature) can be found in coastal regions for ERA-40/ERA-Interim and MERRA, and are more pronounced during positive (negative) phases of the NAO. 20CRv2 shows biases over the entire North Sea and all seasons of several hectopascals. ERA-40 and ERA-Interim show a negative 2-m air temperature bias relative to KNSC along the coastal mainland of Europe, especially during winter months, possibly a result of a remaining land influence. Mean differences result from winter and fall, mostly remaining within measurement uncertainties. Despite the upgrades in the model setup, ERA-Interim shows negligible differences from ERA-40. 20CRv2 and MERRA show positive (negative) biases during the summer (winter) half year. NCEP-1 follows ERA-40/ERA-Interim but mostly with slightly higher differences. All five reanalyses reproduce the decadal variability and climate shift signals present in KNSC fields. Overall, only 20CRv2 has to be considered as clearly unsatisfactorily regarding biases, MAE, and RMSE compared to all other datasets investigated. This study suggests that similar intercomparison studies, performed over other parts of the world's oceans, especially coastal regions, can be very helpful in identifying shortcomings in atmospheric reanalysis products.
\end{abstract}

\section{Introduction}

Atmospheric reanalysis products are often-but erroneously-used synonymously with observations and then are used to build the foundation for so-called observations-based climate and climate change studies in the atmosphere. Moreover, they usually serve as the reference against which climate models are being assessed, especially on the regional scale. However, all

Corresponding author: Dr. Nils H. Schade, nils.schade@bsh.de reanalyses suffer from various shortcomings, as several studies have demonstrated before (e.g., McVicar et al. 2008; Bosilovich et al. 2008). Shortcomings do not only result from inhomogeneities (in space and time) in the datasets being assimilated (the so-called observational shock; e.g., Pawson and Fiorino 1999) and the information about data uncertainties used in this process (e.g., Ferguson and Villarini 2012), but also-like for any other model-from numerical deficits and from uncertainties in parameterizations (e.g., John and Soden 2007; Thorne and Vose 2010). Limitations therefore 
have to be expected in any reanalysis product, as can be readily inferred from the spread that results from a comparison of all available reanalysis products. This is especially obvious in data-sparse regions like the Arctic (Lindsay et al. 2014; Screen and Simmonds 2011) but, in fact, it holds everywhere. Some reanalysis parameters remain especially error prone, such as precipitation over land, which is caused by problems with the input data (e.g., the assimilation of rain-affected radiance data from satellites in ERA-Interim) and by model biases (e.g., enhanced evaporation compared to observations; WCRP 2012). Nevertheless, the atmospheric reanalysis fields, including surface flux products, have greatly improved globally since the advent of the satellite era (mid- to late 1970s) as result of the increased availability of observations with quasi-global coverage (e.g., Kistler et al. 2001; Sterl 2004; Davis 2007).

One way to document shortcomings in reanalysis products is to compare them against independent datasets not being used in the assimilation process. Many of those studies exist over land because of the ample regional availability of in situ observations; a typical example is the comparison study of Betts et al. (2003), which revealed a seasonal air temperature bias in the ERA-40 data in the Mackenzie River basin, presumably resulting from excess evaporation in summer and a toolow albedo for snow in winter. However, observations are much sparser over the global oceans and comparison studies with reference datasets are therefore more difficult. Possibly the best known and widely used long-term ocean reference dataset is the International Comprehensive Ocean-Atmosphere Data Set (ICOADS; Worley et al. 2005; Woodruff et al. 2011, Freeman et al. 2017), a collection of voluntary observing ships (VOS; e.g., WMO 1994) and historic data archives from research, naval and light vessels, and buoys. An example for the use of ICOADS for testing atmospheric reanalysis products can be found in Bedacht et al. (2007).

The marine climatology introduced in this study is an improved reference dataset on the regional scale for the North Sea area. It is used to assess the quality of five different atmospheric reanalyses in this area. The dataset is built from the archive of the Centre for Global Marine Meteorological Observations [Globales Zentrum für Schiffswettermeldungen (GZS); see Schade et al. 2013] of the German Weather Service [Deutscher Wetterdienst (DWD)]. The study is performed as part of the interdisciplinary research program Climate Water Navigation (KLIWAS; BMVI 2016) to investigate potential consequences of climate change for navigation on coastal waterways and coastal protection using regional climate models (RCMs).
Based on investigations using 2-m air temperatures (AT) and sea level pressure (SLP) data in two small regions over the open sea and near the coast (Schade et al. 2013), a gridded climatology was established from the GZS archive as part of this study for the whole North Sea area. This product, the KLIWAS North Sea Climatology (KNSC), currently includes the atmospheric parameters 2-m air and dewpoint temperatures and sea level pressure, as well as salinity and water temperature at different depth levels in the ocean on a compatible horizontal grid. The dataset is planned to be updated regularly in the future and will be expanded to include more parameters. All technical aspects referencing KNSC's atmospheric part are described in detail in Part I of this two-part paper (Sadikni et al. 2018).

The focus of this paper is on the use of the KNSC to evaluate global reanalysis products in the North Sea area. For this evaluation we chose one member from each reanalysis generation: NCEP-1 from the first generation, ERA-40 from the second generation, and MERRA from the third generation; we completed this ensemble with ERA-Interim and 20CRv2. The latter product was chosen because of its unique character; it is based solely on the assimilation of sea level pressure observations throughout the twentieth century, which reduces the uncertainty, since the observational method for sea level pressure changed least over time. Also, 56 ensemble members are used for its compilation, which for the first time provides uncertainty estimates of all errors mentioned above in one reanalysis system by investigations of the ensemble mean and spread (i.e., the upper and lower ends of the ensemble).

The remainder of this paper is organized as follows: Data and methods used will be described in sections 2 and 3, respectively. Results will be discussed in section 4 for 2-m air temperature and sea level pressure variability on various time scales, including the seasonal cycle and annual means. A discussion and concluding remarks will follow in sections 5 and 6 , respectively.

\section{Datasets}

In this section we will introduce the KLIWAS North Sea climatology and the five global atmospheric reanalysis products. The methodology used for the intercomparisons is described in the following section.

\section{a. KNSC}

The KNSC was developed in cooperation with the Federal Maritime and Hydrographic Agency [Bundesamt für Seeschifffahrt und Hydrographie (BSH)], DWD, and the Integrated Climate Data Center (ICDC) of the Centrum für Erdsystemforschung und Nachhaltigkeit (CEN) 
of the University of Hamburg. KNSC is a gridded climatology and consists of a hydrographic and an atmospheric component; the latter is described in detail by Sadikni et al. (2018). KNSC includes the parameters 2-m air and dewpoint temperature and sea level pressure, as well as salinity and water temperature over the water column as monthly and yearly mean fields on a compatible grid. The meteorological parameters are available on a $1^{\circ} \times 1^{\circ}$ grid from 1950 to 2010 and the hydrographic ones on a $0.25^{\circ} \times 0.5^{\circ}$ grid from 1890 to 2011. KNSC data for both the atmospheric and hydrographic parts are available online (https://icdc.cen.unihamburg.de/daten.html) and at the World Data Centre for Climate (WDCC) at the German Climate Computing Centre [Deutsches Klimarechenzentrum GmbH (DKRZ; Bersch et al. 2013; Sadikni et al. 2013].

The atmospheric component of the climatology is based on the quality-controlled GZS data containing measurements from platforms such as VOS; drifting and moored buoys; research, naval, and light vessels; offshore platforms (e.g., oil rigs); and digitized data from historical marine weather journals (Kaspar et al. 2015) and registrations. In essence, GZS holds the same data as ICOADS (see Schade et al. 2013), since most of the actual reports are collected automatically via the international Global Telecommunication System (GTS; see WMO 1988; WMO 2015). Time-lagged contributions from ICOADS in GZS are about $3.5 \%$ today and decreasing.

\section{b. ERA-40}

The global ERA-40 (Uppala et al. 2005) is provided by the European Centre for Medium-Range Weather Forecasts (ECMWF). It covers the period from 1957 to 2002 and contains meteorological parameters at 60 vertical levels up to $0.1 \mathrm{hPa}$ with a temporal resolution of $6 \mathrm{~h}$. The assimilation system is based on the threedimensional variational data assimilation (3D-VAR; e.g., Lorenc 1986) of ECMWF at a spectral T159 resolution, corresponding to approximately $112-\mathrm{km}$ spacing on a reduced Gaussian grid. Among the assimilated observational data types are satellite data (since 1973). The surface parameters are derived by optimum interpolation from the lowest model level and the surface skin temperatures (Simmons et al. 2004).

\section{c. ERA-Interim}

ERA-Interim (Berrisford et al. 2009; Dee et al. 2011) is an updated version of ERA-40, spanning the period from 1979 to the present, with several improvements implemented, such as enhanced horizontal resolution, a 4D-VAR system, and a completely automated system for correcting biases in satellite radiance observations.
The latter is of particular significance, since the majority of assimilated observations now originate from satellites. The model configuration has a spectral T255 horizontal resolution, which corresponds to approximately $79-\mathrm{km}$ spacing on a reduced Gaussian grid. The vertical resolution of the atmospheric model is unchanged compared to ERA-40 (Dee et al. 2011); the 2-m air temperature is derived through optimum interpolation as well but using the 2-m air temperature and background temperatures from the previous time step.

\section{d. NCEP-1}

The National Centers for Environmental Prediction (NCEP) and the National Center for Atmospheric Research (NCAR) produced NCEP-1 (Kalnay et al. 1996) in close cooperation. The central module is identical to the operational system then used at the NCEP but with a spectral T62 horizontal resolution, that is, about $210-\mathrm{km}$ grid spacing and 28 vertical levels. The reanalysis was initially completed in 1996, but it continued through an identical Climate Data Assimilation System (CDAS) to ensure consistency with earlier decades. As for the ECMWF reanalyses, the 2-m air temperature is interpolated from the skin temperature and the lowest model layer. The temporal resolution is $6 \mathrm{~h}$.

\section{e. MERRA}

The Modern-Era Retrospective Analysis for Research and Applications (MERRA; Rienecker et al. 2011) was generated by NASA's Global Modeling and Assimilation Office with version 5.2.0 of the Goddard Earth Observing System Model (GEOS) Data Assimilation System (DAS). It covers the "modern satellite era" from 1979 to the present. The objectives were to place observations from the Earth Observing System (EOS) satellites into a climate context and to improve the representation of the hydrologic cycle compared to earlier generations of reanalyses. At a horizontal resolution of $0.5^{\circ} \times 0.67^{\circ}$ (latitude, longitude), 72 vertical levels, and an hourly output of the $2 \mathrm{D}$ diagnostics, the resolution is the highest among the atmospheric reanalysis products used here. MERRA uses a 3D-VAR assimilation algorithm that was originally developed by NCEP. The assimilation system will not be updated to ensure a continuous product. The inherent quality might fluctuate as new instruments or measurement techniques are introduced. Thus, the trends in many fields might be affected.

\section{f. $20 C R v 2$}

The Twentieth Century Reanalysis (20CR) project (Compo et al. 2011) was initiated to produce a 
comprehensive global atmospheric circulation dataset spanning the entire twentieth century, assimilating only surface observations of synoptic pressure from the International Surface Pressure Databank, version 2 (ISPDv2; Cram et al. 2015). The HadISST monthly sea surface temperature and sea ice distribution (Rayner et al. 2003) are used as boundary conditions. 20CR uses an ensemble Kalman filter data assimilation method (Whitaker and Hamill 2002) that includes 56 ensemble members, each of which provides a 6-hourly analysis as the most likely state of the global atmosphere; therefore, each member provides estimates of the uncertainty in the analysis. The second version20CR, version 2 (20CRv2)-which is used here, now provides information spanning from 1871 to 2012 at a 6-hourly temporal and $2^{\circ}$ horizontal resolution on 24 pressure levels.

\section{Methods and preprocessing}

In this study the intercomparisons are restricted to "wet" grid cells over the North Sea area using the respective land-sea masks provided by each reanalysis. However, ERA-40 and ERA-Interim are partially influenced by land at coastal grid cells, resulting in noticeable temperature differences, especially during wintertime (Schade et al. 2013). Differences between the reanalyses and KNSC, and intermodel mean absolute errors (MAE) and root-mean-square errors (RSME) were calculated at their respective lower grid resolutions. All mean fields, composite analyses, frequency distributions, RMSE, MAE, and annual cycles were calculated from 1979 to 2001, during which all datasets overlap to assure comparable statistics. Since this period spans only 22 years, the statistics are less reliable, simply as a result of the reduced amount of data used, and might change if 30 or more years were to be considered. Moreover, the use of longer periods would imply that each reanalysis dataset would have to span a different period. This in turn would insert additional differences as a result of natural (e.g., decadal) variations and changes in the assimilation of input data. For example, prior to 1979 , satellite data were not assimilated (if available at all), leading to the abovementioned "observational shock." Therefore, the use of an overlapping period is preferable for these intercomparisons. However, time series are discussed over the full length of the period covered by KNSC (i.e., 1950-2010).

Time-mean field and composite analyses for years with positive phases of the North Atlantic Oscillation $(\mathrm{NAO}+)$ and negative phases $(\mathrm{NAO}-)$ are presented for both sea level pressure and 2-m air temperature over the whole North Sea area as shown in Fig. 1. To investigate

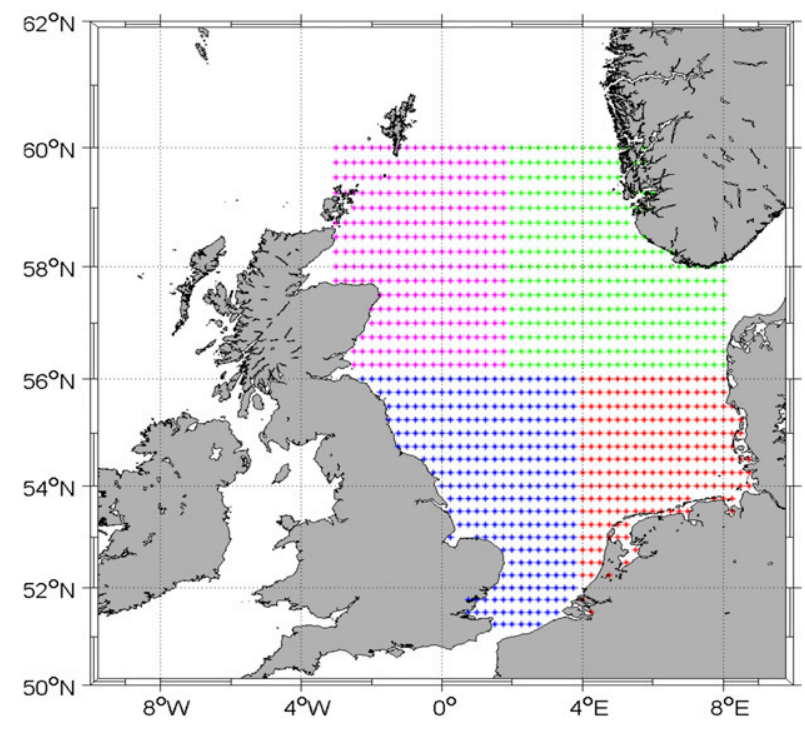

FIG. 1. North Sea area, divided into four geographical different subregions (NW: magenta, NE: green, SW: blue, SE: red).

regional differences, annual cycles, frequency distributions, and time series were analyzed in four subregions of the North Sea. These subregions were chosen according to the comparability of the regional climate, the ratio of open sea to coastal grid cells, and the total number of grid cells. For the calculation of the annual cycles, monthly means and standard deviations were evaluated first for each grid cell; the spatial means for each subregion were calculated subsequently. To calculate the time series, first, the annual mean values were evaluated for grid cells, then the spatial means for each subregion. Frequency distributions were concatenated over all monthly means and all grid cells in each subregion.

\section{Results}

\section{a. Mean fields, MAE, and RMSE in the North Sea area}

Averages of SLP and 2-m AT for the period from 1979 to 2001 show distinct patterns in KNSC (Fig. 2): The SLP field displays a northwest-southeast gradient in the annual mean, resulting mainly from winter (DJF) and fall (SON) pressure fields (Fig. 3, top) related to NAO, when the gradient is most pronounced. Spring (MAM) and summer (JJA) gradients are weaker but still evident. The area of highest SLP values in the English Channel region is maintained during all seasons. Here, the highest SLP values of about $1018 \mathrm{hPa}$ occur in summer.

The AT field off the coast generally follows the sea surface temperature (SST, not shown). Figure 3 (bottom) displays a distinct warming of shallow water in the 

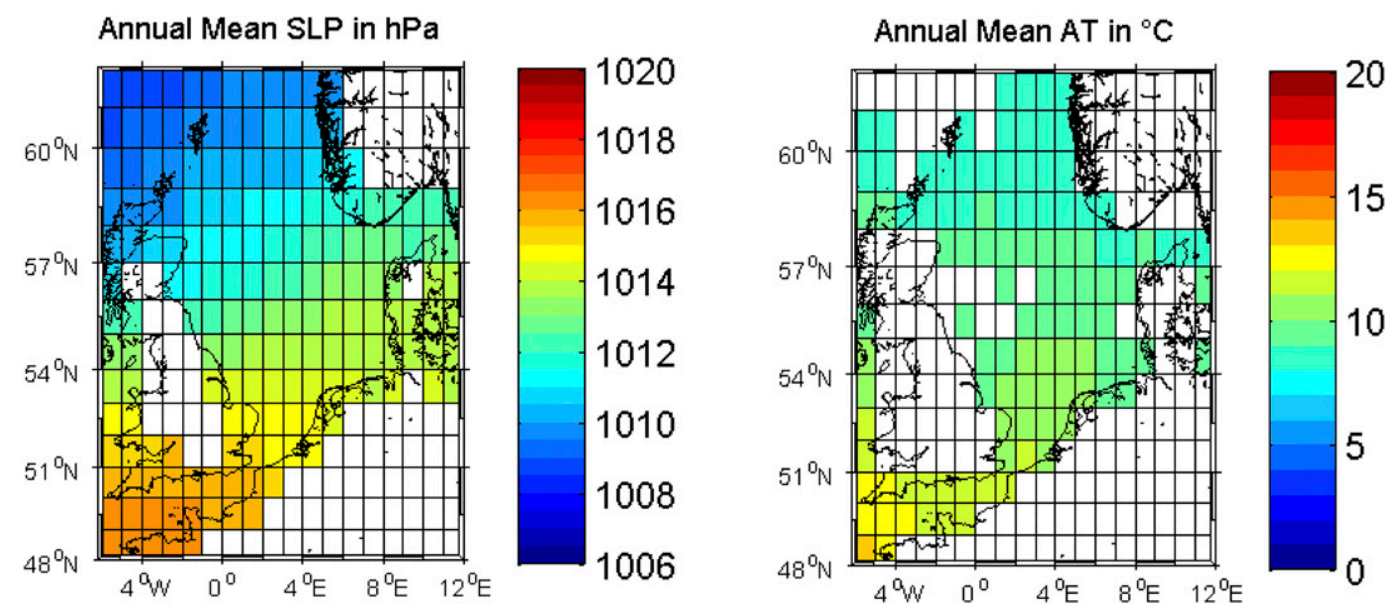

FIG. 2.. Annual mean values of KNSC (left) SLP (hPa) and (right) 2-m AT ( $\left.{ }^{\circ} \mathrm{C}\right)$ for the base period 1979-2001.

coastal areas of mainland Europe in summer (up to $18^{\circ} \mathrm{C}$ ) and fall and a cooling in winter and spring. A similar gradient to the SLP fields is evident in summer and fall, resulting from the warmer adjacent landmasses and the inflow of warm Atlantic waters eastward through the English Channel. Therefore, highest AT values are found in the English Channel region, reaching up to Denmark and the Baltic inflow/outflow region in summer. A northeast-southwest gradient, resulting from cooling of the landmasses in the winter half year and warm Atlantic current inflow can be seen in the other seasons and the annual mean.

Annual and seasonal mean differences of SLP and AT between individual reanalyses and KNSC are presented in Figs. 4-6 for the period 1979-2001. ERA-40, ERA-Interim, and MERRA all show higher SLP values
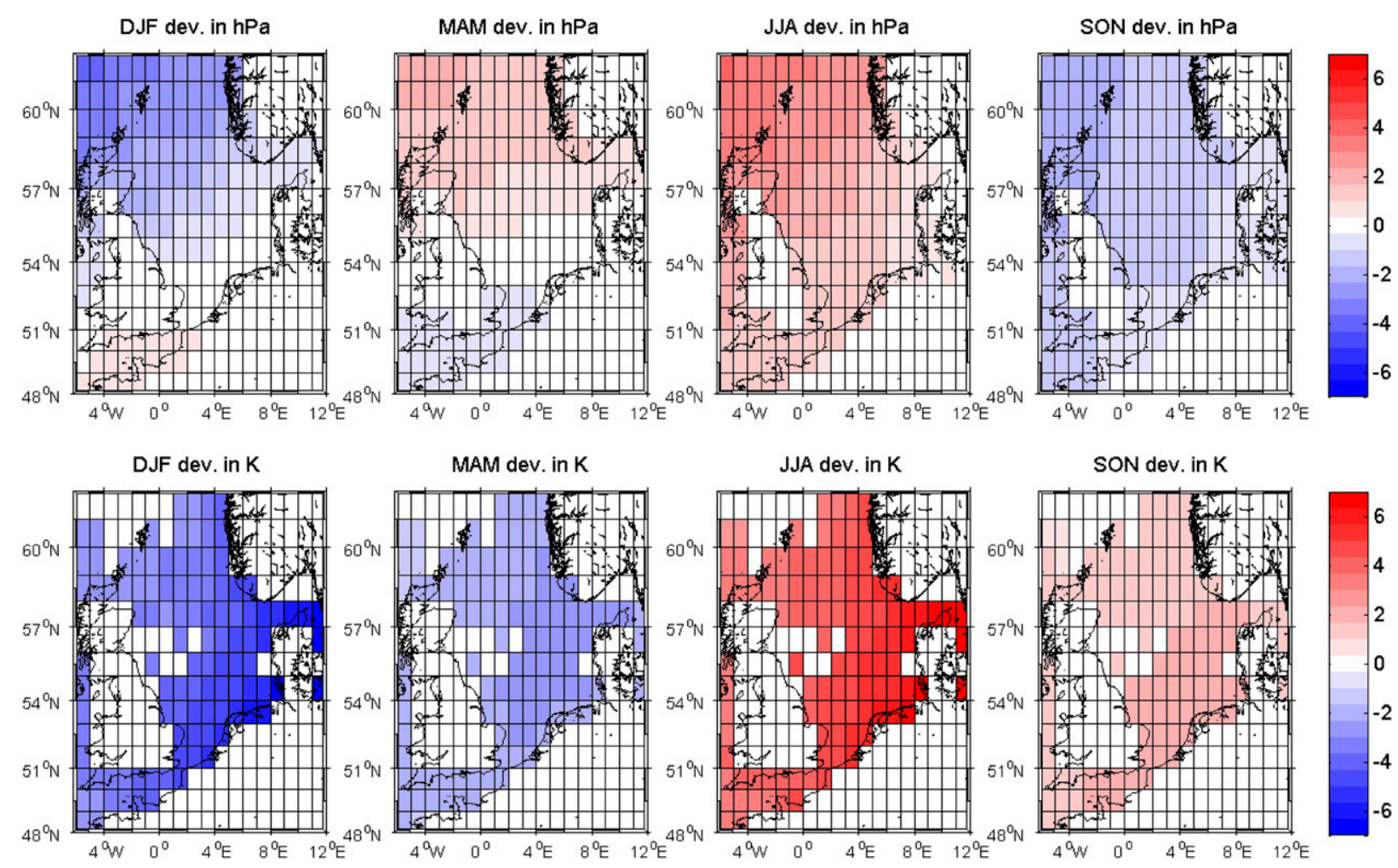

SON dev. in $\mathrm{K}$

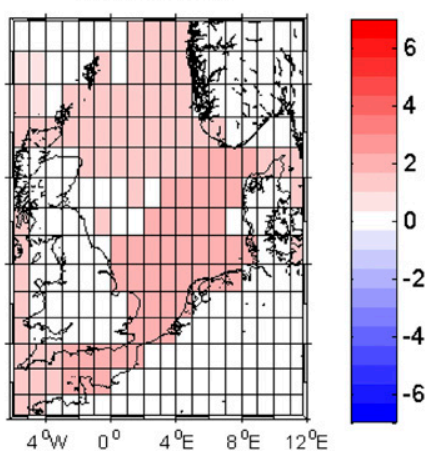

FIG. 3. Difference between KNSC seasonal mean (winter: DJF, spring: MAM, summer: JJA, fall: SON) (top) SLP (hPa) and (bottom) 2-m AT (K) to the annual mean values (see Fig. 2) for the base period 1979-2001. 

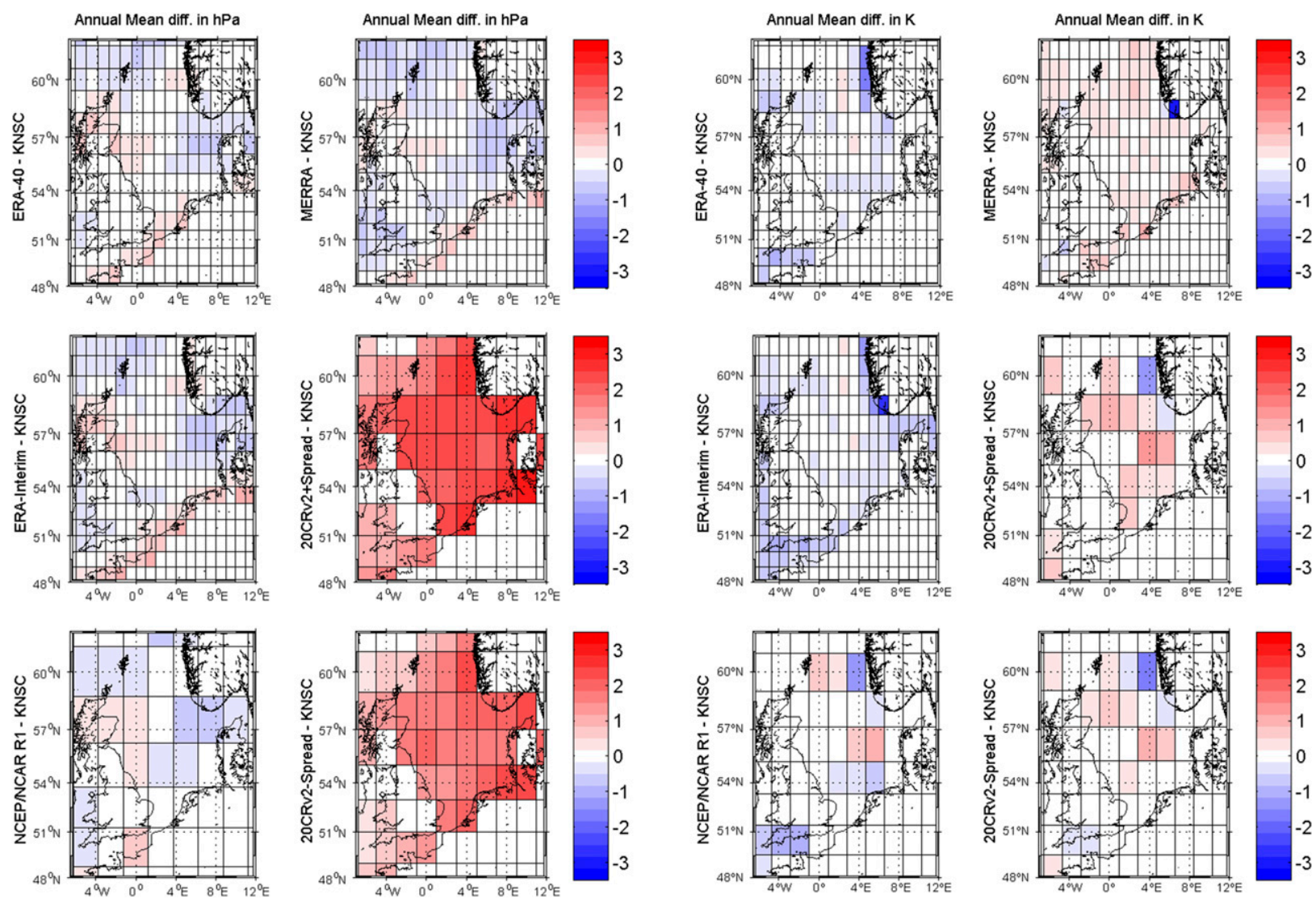

FIG. 4. Difference in annual mean (left) SLP (hPa) and (right) 2-m AT (K) between reanalyses (ERA-40, ERA-Interim, NCEP-1, MERRA, 20CRv2 mean plus spread, and 20CRv2 mean minus spread) and KNSC for the base period 1979-2001.

in coastal regions of mainland Europe, Scotland up to Norway, and the English Channel of 1-2 hPa (Fig. 4, left two columns), resulting mainly from fall and winter (Fig. 5). For the other seasons there is a better agreement: Differences in the range of $\pm 0.75 \mathrm{hPa}$ can be found in coastal regions and considerably less in the open North Sea, with a slight underestimation of SLP compared to KNSC. NCEP-1 shows slightly higher values around the northern parts of the British Isles and in the English Channel, while the other regions show a slightly smaller range of values between -0.75 and $0.25 \mathrm{hPa}$. Coastal areas show no prominent deviations. Altogether, differences are clearly within the range of the random error estimates of $2.4 \pm 0.9 \mathrm{hPa}$ for the North Sea area derived by Kent and Berry (2005), and the respective standard deviations (see section $4 \mathrm{~b}$ ).

However, 20CRv2 stands as an exception in this comparison: Despite the fact that it has been based on SLP observations over sea solely, SLP in the whole North Sea area is overestimated by $1-2 \mathrm{hPa}$ (lower end of the ensemble $=$ mean minus spread) and up to $2-3 \mathrm{hPa}$ (upper end of the ensemble $=$ mean plus spread), showing more pronounced differences in the winter half year (see also section $4 \mathrm{~b}$ ). Especially the upper end of the ensemble exceeds the aforementioned random error estimates (Kent and Berry 2005) during the winter months.

The MAEs and RMSEs presented in Table 1 show the best accordance between ERA-40 and ERA-Interim ( 0.04 and $0.05 \mathrm{hPa}$, respectively), which is not utterly surprising, since ERA-Interim is an improved version of ERA-40. ERA-40's mean SLP fits best to KNSC, regardless of whether MAE $(0.23 \mathrm{hPa})$ or RMSE $(0.29 \mathrm{hPa})$ is considered, although the mean value differs more from KNSC than ERA-Interim's and MERRA's mean values. 20CRv2's upper end of the ensemble (20CRv2 upper) shows the highest MAE $(1.80 \mathrm{hPa})$ and RMSE $(2.35 \mathrm{hPa})$ compared to KNSC. The latter also has the highest values of MAE. RMSE is especially high for the combination of MERRA and 20CRv2 upper $(2.36 \mathrm{hPa})$, but also for the combination of KNSC and 20CRv2 upper. In general, 20CRv2related MAEs and RMSEs are within $2 \pm 0.36 \mathrm{hPa}$ in whatever combination. 

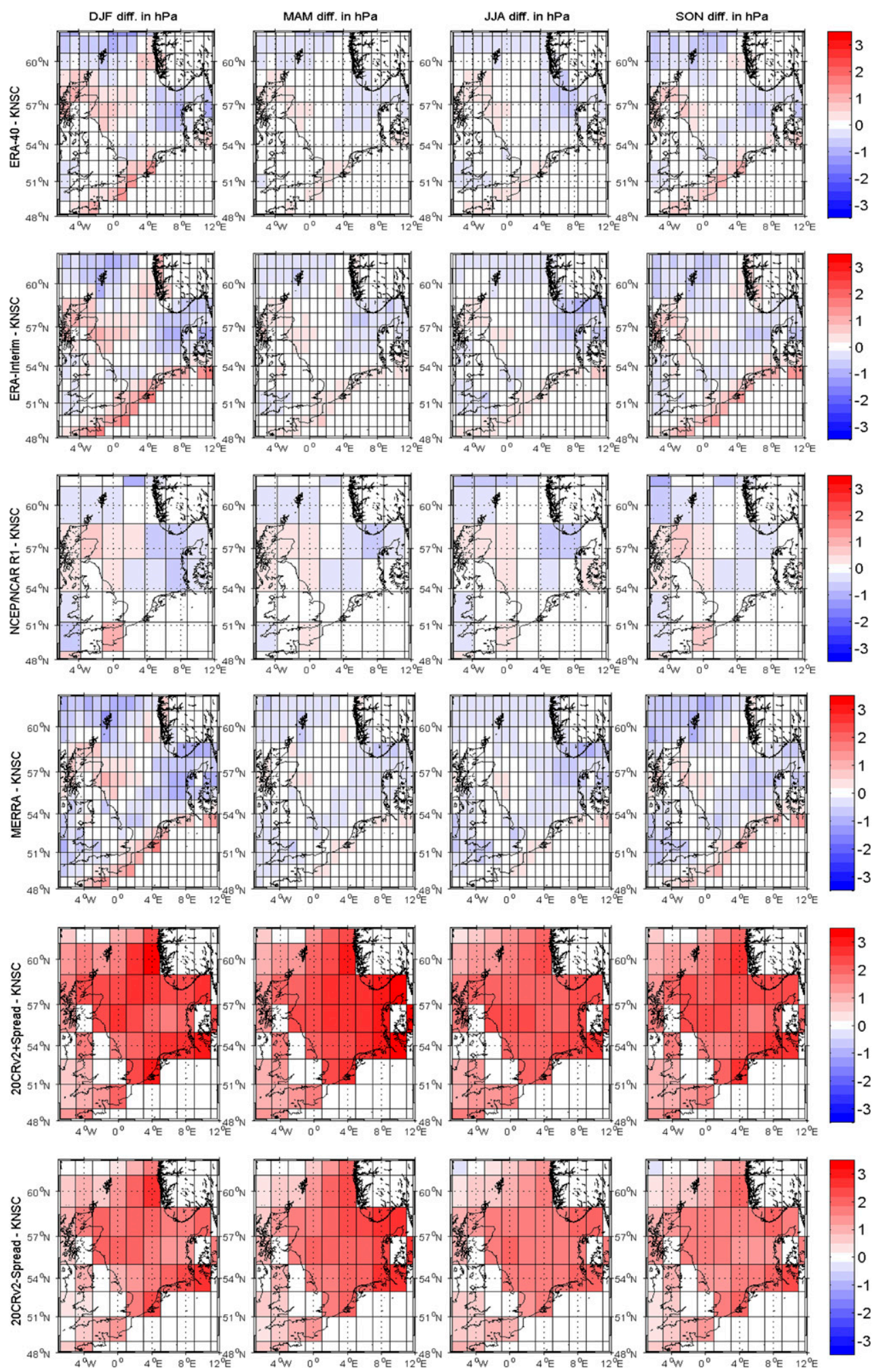

FIG. 5. As Fig. 4, but for seasonal mean SLP (hPa) (winter: DJF, spring: MAM, summer: JJA, fall: SON). 
TABLE 1. Comparison of mean SLP fields (1979-2001). Mean SLP over the four subregions of the North Sea (see Fig. 1) depicted by KNSC and the reanalyses (first row). The two cross matrices give MAE and RMSE between the datasets. Bold (italic) numbers mark the respective highest (lowest) values.

\begin{tabular}{|c|c|c|c|c|c|c|c|}
\hline & KNSC & ERA-40 & ERA-Interim & NCEP & MERRA & 20CRv2 lower & 20CRv2 upper \\
\hline Mean $(\mathrm{hPa})$ & 1012.7 & 1013.2 & 1013.0 & 1013.4 & 1013.1 & 1015.1 & 1015.7 \\
\hline \multicolumn{8}{|c|}{ MAE (hPa) } \\
\hline KNSC & 0.0 & 0.23 & 0.27 & 0.27 & 0.28 & 1.80 & 2.35 \\
\hline ERA-40 & 0.23 & 0.0 & 0.04 & 0.10 & 0.20 & 1.64 & 2.17 \\
\hline ERA-Interim & 0.27 & 0.04 & 0.0 & 0.08 & 0.16 & 1.65 & 2.19 \\
\hline NCEP & 0.27 & 0.10 & 0.08 & 0.0 & 0.17 & 1.67 & 2.21 \\
\hline MERRA & 0.28 & 0.20 & 0.16 & 0.17 & 0.0 & 1.80 & 2.34 \\
\hline 20CRv2 lower & 1.80 & 1.64 & 1.65 & 1.67 & 1.80 & 0.0 & 0.54 \\
\hline 20CRv2 upper & 2.35 & 2.17 & 2.19 & 2.21 & 2.34 & 0.54 & 0.0 \\
\hline \multicolumn{8}{|c|}{ RMSE (hPa) } \\
\hline KNSC & 0.0 & 0.29 & 0.34 & 0.32 & 0.34 & 1.82 & 2.36 \\
\hline ERA-40 & 0.29 & 0.0 & 0.05 & 0.11 & 0.27 & 1.68 & 2.20 \\
\hline ERA-Interim & 0.34 & 0.05 & 0.0 & 0.10 & 0.20 & 1.69 & 2.22 \\
\hline NCEP & 0.32 & 0.11 & 0.10 & 0.0 & 0.23 & 1.71 & 2.24 \\
\hline MERRA & 0.34 & 0.27 & 0.20 & 0.23 & 0.0 & 1.83 & 2.36 \\
\hline 20CRv2 lower & 1.82 & 1.68 & 1.69 & 1.71 & 1.83 & 0.0 & 0.55 \\
\hline 20CRv2 upper & 2.36 & 2.20 & 2.22 & 2.24 & 2.36 & 0.55 & 0.0 \\
\hline
\end{tabular}

AT differences reveal coastal effects in terms of lower annual mean temperatures (Fig. 4, right two columns), resulting mainly from winter and fall for ERA-40 and ERA-Interim (Fig. 6), and higher annual mean temperatures, resulting from summer and spring for MERRA and 20CRv2 (Figs. 4 and 6). MERRA in general shows higher temperatures over the entire North Sea, especially over the open sea in winter and fall. 20CRv2 shows the most pronounced differences in the annual means, with a warm bias over the entire area except a "cold spot" off the Norwegian coast. NCEP-1 has warmer ATs off the Danish coast and colder ATs in the English Channel, the southern North Sea, and off the shores of Norway. This "Norwegian cold bias" is apparent in all the reanalyses investigated here. The orographic characteristics, steeply rising mountain edges facing predominantly westerly winds, seem to enhance the cooling effect. MERRA is the least affected; only one cell shows pronounced colder temperatures. Interestingly, it is the same grid cell (with a predominant land fraction) in which ERA-Interim deviates most. Further, the AT differences of $1-2 \mathrm{~K}$ compared to KNSC are of the same order of magnitude as described by Schade et al. (2013) and mostly within the range of the random measurement errors found by Kent and Berry (2005). An exception is the Norwegian cold bias region, where these errors are exceeded.

MAEs and RMSEs for AT show the best accordance between ERA-40 and ERA-Interim (MAE $=0.14 \mathrm{~K}$, RMSE $=0.24 \mathrm{~K}$; see Table 2) as well, while ERA-40 fits best to KNSC (MAE $=0.26 \mathrm{~K}, \mathrm{RMSE}=0.38 \mathrm{~K}$ ). MERRA is closest to KNSC in the mean AT, but it can be seen from Fig. 4 that it results from one very cold spot on the coast of Norway that was added to the otherwise small positive differences. Therefore, MAE and RMSE between KNSC and MERRA are higher than the combinations of KNSC and ERA-Interim/ERA-40. The upper end of the 20CRv2 ensemble deviates most from $\mathrm{KNSC}(\mathrm{MAE}=0.62 \mathrm{~K}, \mathrm{RMSE}=0.70 \mathrm{~K})$. The combination 20CRv2 upper and ERA-Interim shows the highest MAE (1.05 K), and 20CRv2 upper and MERRA show the highest RMSE $(1.48 \mathrm{~K})$.

\section{b. Annual cycles}

Annual cycles are presented in Fig. 7 for the four North Sea subregions displayed in Fig. 1. It shows lower pressure values for KNSC in the northern subregions with the exception of May, while differences are highest in the winter half year. Air temperatures are highest in the southern subregions for the summer half year and coldest in the eastern subregions for the winter half year, when the cooling effect from the adjacent land is highest.

All reanalyses except for 20CRv2 are close to KNSC SLP values, with slightly larger differences in the southern part of the North Sea (Fig. 8). All 20CRv2 ensemble members approximately follow the same annual cycle, but with less spread during the summer half year and with a pronounced offset of several hectopascals (hPa). Maximum differences close to $4 \mathrm{hPa}$ can be found in the southeastern subregion for the upper 

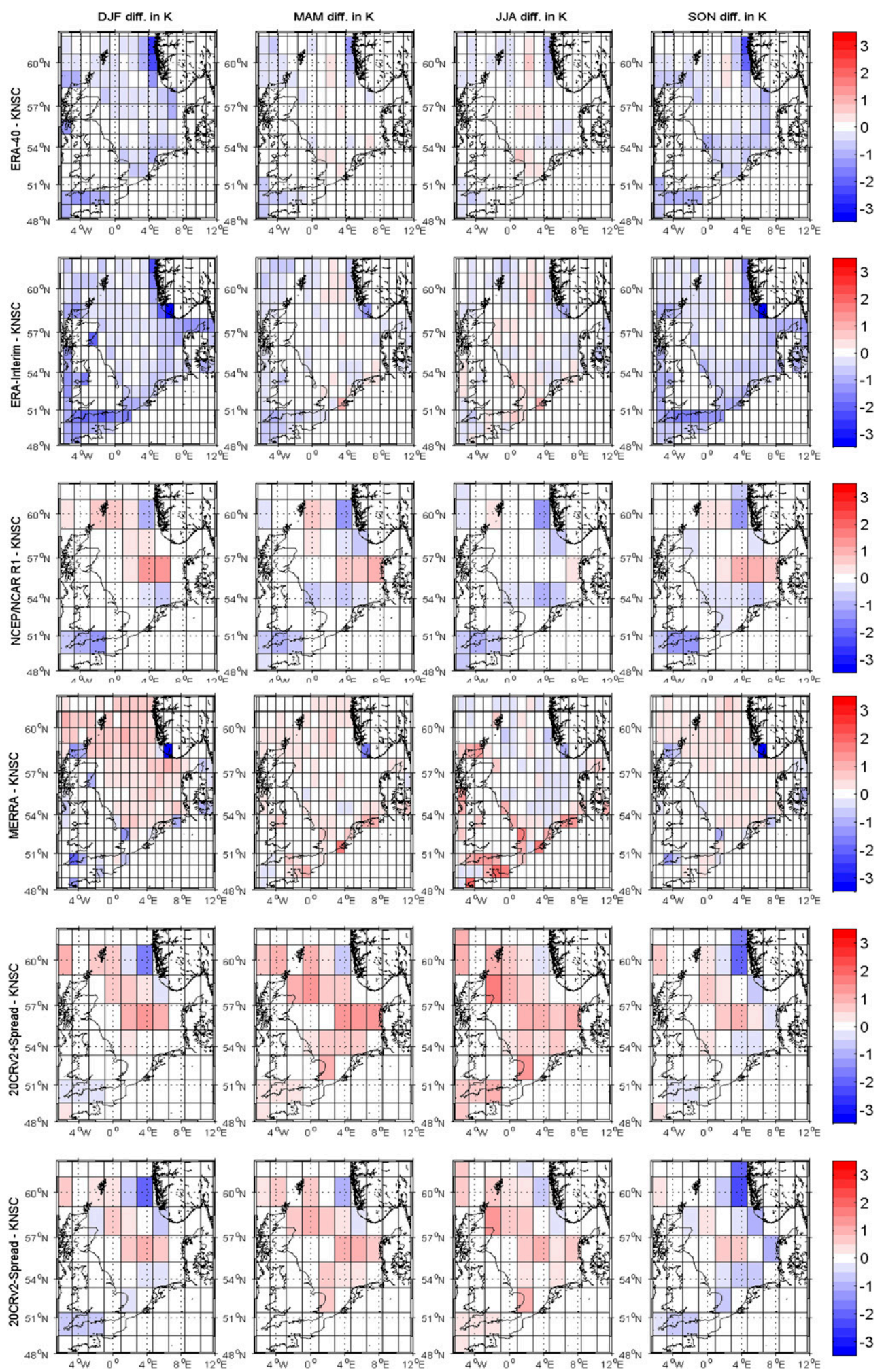

Fig. 6. As Fig. 4 but for seasonal mean 2-m AT (K) (winter: DJF, spring: MAM, summer: JJA, fall: SON). 
TABLE 2. As in Table 1, but for mean 2-m AT fields (1979-2001).

\begin{tabular}{|c|c|c|c|c|c|c|c|}
\hline & KNSC & ERA-40 & ERA-Interim & NCEP & MERRA & 20CRv2 lower & 20CRv2 upper \\
\hline Mean $\left({ }^{\circ} \mathrm{C}\right)$ & 9.48 & 8.99 & 8.98 & 8.97 & 9.42 & 9.30 & 9.74 \\
\hline \multicolumn{8}{|c|}{$\operatorname{MAE}(\mathrm{K})$} \\
\hline KNSC & 0.0 & 0.26 & 0.27 & 0.39 & 0.28 & 0.43 & 0.62 \\
\hline ERA-40 & 0.26 & 0.0 & 0.14 & 0.34 & 0.52 & 0.60 & 1.00 \\
\hline ERA-Interim & 0.27 & 0.14 & 0.0 & 0.44 & 0.45 & 0.65 & 1.05 \\
\hline NCEP & 0.39 & 0.34 & 0.44 & 0.0 & 0.65 & 0.53 & 0.88 \\
\hline MERRA & 0.28 & 0.52 & 0.45 & 0.65 & 0.0 & 0.65 & 0.92 \\
\hline 20CRv2 lower & 0.43 & 0.60 & 0.65 & 0.53 & 0.65 & 0.0 & 0.32 \\
\hline 20CRv2 upper & 0.62 & 1.00 & 1.05 & 0.88 & 0.92 & 0.32 & 0.0 \\
\hline \multicolumn{8}{|c|}{ RMSE (K) } \\
\hline KNSC & 0.0 & 0.38 & 0.44 & 0.51 & 0.46 & 0.58 & 0.70 \\
\hline ERA-40 & 0.38 & 0.0 & 0.24 & 0.47 & 0.71 & 0.69 & 1.10 \\
\hline ERA-Interim & 0.44 & 0.24 & 0.0 & 0.56 & 0.56 & 0.87 & 1.24 \\
\hline NCEP & 0.51 & 0.47 & 0.56 & 0.0 & 0.95 & 0.71 & 1.09 \\
\hline MERRA & 0.46 & 0.71 & 0.56 & 0.95 & 0.0 & 1.27 & 1.48 \\
\hline 20CRv2 lower & 0.58 & 0.69 & 0.87 & 0.71 & 1.27 & 0.0 & 0.33 \\
\hline 20CRv2 upper & 0.70 & 1.10 & 1.24 & 1.09 & 1.48 & 0.33 & 0.0 \\
\hline
\end{tabular}

boundary in the winter months. Nevertheless, with the exception of 20CRv2, all reanalyses agree within $\pm 1 \mathrm{hPa}$ throughout the year in all four subregions, and even within $0.5 \mathrm{hPa}$ in the northeastern subregion.

The annual AT cycle differences (Fig. 9) show the best agreement with KNSC for ERA-40/ERA-Interim and NCEP-1 within about $0.5 \mathrm{~K}$ throughout the year and slightly better during the summer months. MERRA agrees well in the northwestern subregion and slightly less in the northeastern subregion, whereas the values in the southern North Sea vary considerably, especially in the southeast, where the annual cycle is underestimated by $\sim 2 \mathrm{~K}$ in winter and overestimated by $\sim 1.3 \mathrm{~K}$ in May. As can be seen in Fig. 6, these differences result mainly from coastal grid cells. 20CRv2 annual cycles show differences from KNSC in all four subregions and is most pronounced in the southeastern subregion: The amplitude between wintertime underestimation and summertime overestimation is nearly $4 \mathrm{~K}$ for the whole ensemble, comparable to MERRA.

\section{c. Time series}

SLP and AT time series are shown in Fig. 10 for KNSC in the four North Sea subregions: The complete KNSC period from 1950 to 2010 is presented to address also the long-term characteristics for the pre-satellite-era reanalyses.

In general, the decadal SLP variation seems accurately reproduced by all reanalyses in all subregions (Fig. 11) and, again, with the exception of 20CRv2, the

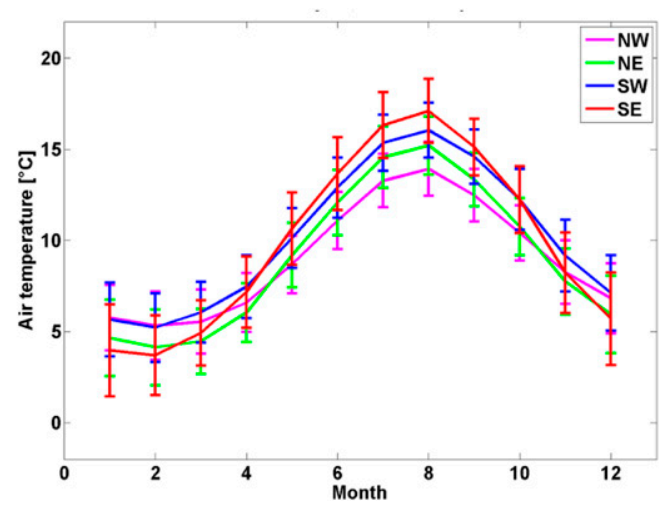

FIG. 7. Annual cycle of (left) area-mean SLP (hPa) and (right) 2-m AT $\left({ }^{\circ} \mathrm{C}\right)$ for KNSC in the four North Sea subregions (NW: magenta, NE: green, SW: blue, SE: red; see Fig. 1) for the base period 1979-2001. Standard deviations are represented by the error bars. 

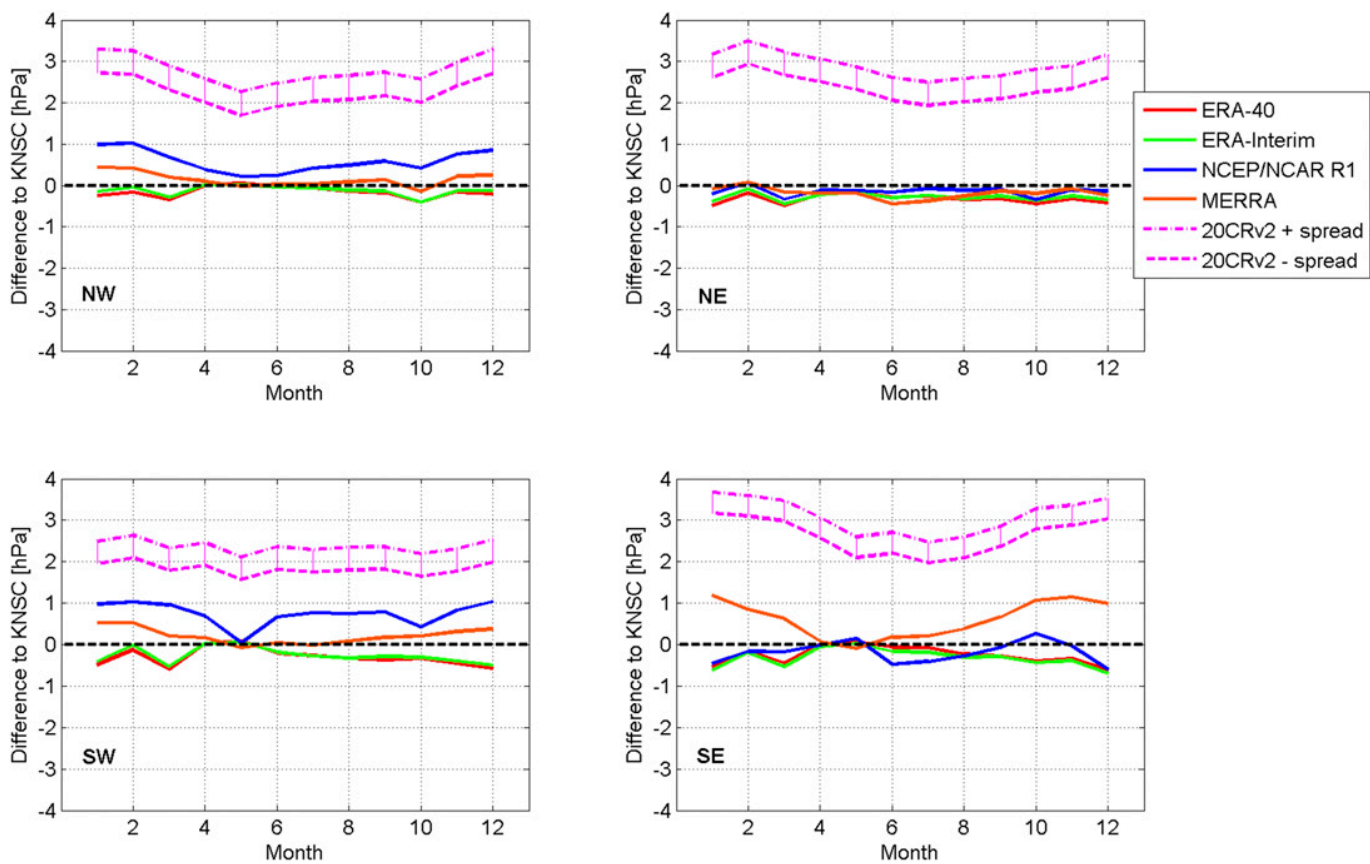

FIG. 8. Difference in the annual cycle of SLP (hPa) between the five reanalyses and KNSC in the four North Sea subregions (NW, NE, SW, SE) for the base period 1979-2001.

agreement with KNSC improves over time. This may be due to the improved observational density, especially since the assimilation of satellite data in the mid- to late 1970s. The differences are slightly smaller in the northern North Sea, but they are always within $\pm 1 \mathrm{hPa}$, while the offset of the 20CRv2 ensemble between 1 and $4 \mathrm{hPa}$ during the whole period is remarkable.

All North Sea subregions reveal a similar decadal AT variability for KNSC (Fig. 10), especially the climate regime shift signal by the end of the 1980s is well
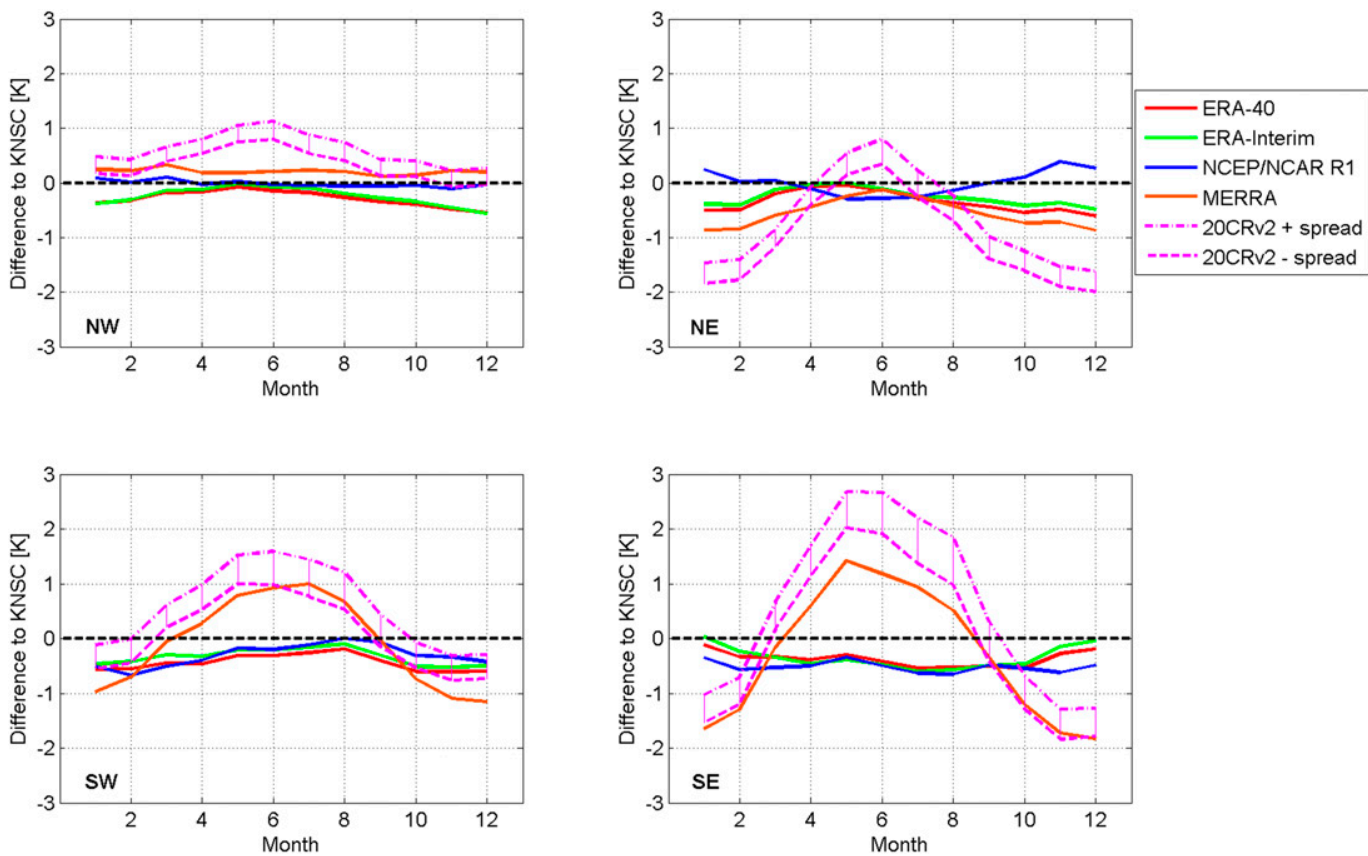

FIG. 9. As in Fig. 8, but for 2-m AT (K). 

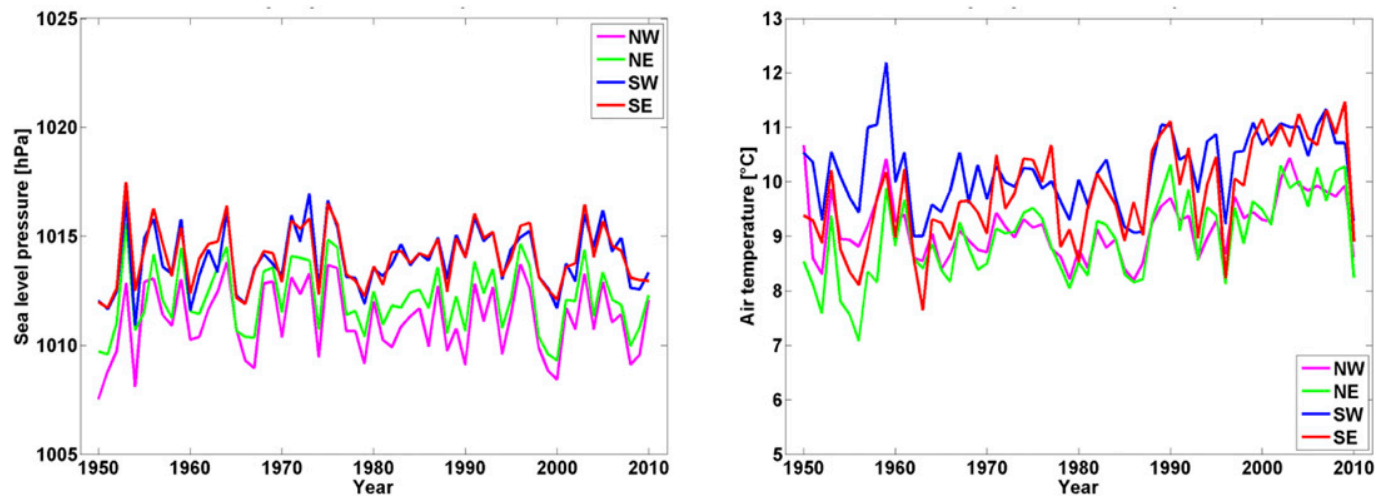

FIG. 10. Annual mean (left) SLP (hPa) and (right) 2-m AT $\left({ }^{\circ} \mathrm{C}\right)$ for KNSC in the four North Sea subregions (NW: magenta, NE: green, SW: blue, SE: red; see Fig. 1) for the base period 1950-2010.

represented, although to a smaller extent in the northwestern subregion. This regime shift has been well documented in the recent literature, not only for the Northern Hemisphere (e.g., Watanabe and Nitta 1999; Francis and Vavrus 2012), but also with pronounced impact on the North Sea's ecosystem (Beaugrand 2004) and in the BSH sea surface temperature data (Loewe 2009). Nevertheless, there are differences between the reanalyses and KNSC and, again, most pronounced for 20CRv2 (Fig. 12). With the exception of the northeastern subregion, the lower boundary of the 20CRv2 ensemble seems to fit well with the other reanalyses and KNSC, but the upper boundary shows a bias of up to
$1 \mathrm{~K}$ in the western subregions and up to $2 \mathrm{~K}$ in the southeastern subregion in the mid- to late 1950s. The northeastern subregion is in particular noteworthy, since in contrast to the other subregions, 20CRv2 fits well with KNSC in the 1950s and shows a nearly constant -0.5 - to $-1.3-\mathrm{K}$ offset (upper to lower ends of the ensemble) by the end of the 1950s. This offset can also be observed for NCEP-1 and partly for ERA-40. Keeping in mind that these years are only sparsely covered by observations (see Sadikni et al. 2018, their Fig. 1), it might be either a natural climate variability signal or the signal might be erroneously introduced during the assimilation process. It also might be


FIG. 11. Difference in annual mean SLP (hPa) between the five reanalyses and KNSC in the four North Sea subregions (NW, NE, SW, SE), for the base period 1950-2010. 



FIG. 12. As in Fig. 11, but for 2-m air temperature (K).

related to the spinup of the reanalyses that start around that time. Further, ERA-40/ERA-Interim yearly mean ATs are closer to KNSC in the northern North Sea if the coastal grid cells are not included in the analyses (not shown) and closer to KNSC in the southern North Sea when coastal grid cells are included. Here, the influence of the Norwegian cold bias cuts through. Overall, the differences are more pronounced during the first half of the investigated period and with the exception of 20CRv2 always within the range of previous investigations in the European region over land (e.g., Simmons et al. 2004).

\section{d. Anomaly fields}

Anomaly fields have been computed for SLP and AT from January to March (JFM) as NAO+ and NAOcomposites compared relative to the time mean from the period 1979-2001. For our further investigations, monthly mean NAO indices from the Climate Prediction Center (CPC, http://www.cpc.ncep.noaa.gov/ products/precip/CWlink/pna/nao.shtml) were used. Indices were derived from the first leading mode of the rotated empirical orthogonal function (REOF) analysis of monthly mean 500-mb heights in the analysis region $20^{\circ}-90^{\circ} \mathrm{N}$ from 1950 to 2000 (Barnston and Livezey 1987). NAO+ years exceed a mean value for the NAO index of +0.5 for the first quarter, whereas $\mathrm{NAO}-$ years exceed a mean index of -0.5 .

Both parameters reveal distinct patterns (Fig. 13): KNSC's SLP field shows an enhanced pressure gradient during $\mathrm{NAO}+$ years and a reduced gradient during NAO- years. The AT field shows enhanced warming in the eastern North Sea during $\mathrm{NAO}+$ and cooling of the coastal regions of mainland Europe with a clear northwest-southeast gradient during $\mathrm{NAO}-$ years. Both can be clearly seen in the anomaly fields. The warming pattern during $\mathrm{NAO}+$ results from enhanced westerly winds caused by the enhanced pressure gradient carrying warm maritime air into the North Sea area. The cooling pattern during NAO - phases can be explained by reduced warm westerly winds and enhanced influence of the continental cold temperatures. Both patterns are reproduced by the reanalyses (not shown); nevertheless, certain differences occur, as presented in the following.

Figure 14 shows the winter differences (JFM) for the whole period 1979-2001 and the respective NAO+ and NAO - years between the reanalyses and KNSC SLP and AT data. Clearly, positive winter SLP differences near the coast for ERA-40/ERA-Interim and MERRA compared to KNSC (Fig. 14, left three columns) arise from $\mathrm{NAO}+$ years, whereas only very small differences can be found during NAO- years. Therefore, it can be assumed that the enhanced coastal SLP values during $\mathrm{NAO}+$ are at least partly a feature of the reanalysis's models and/or other effects, resulting from the coastal stations assimilated (as well as most of the differences in the wintertime pattern as a whole). A comparison with Figs. 4 and 5 reveals that indeed $\mathrm{NAO}+$ phases 


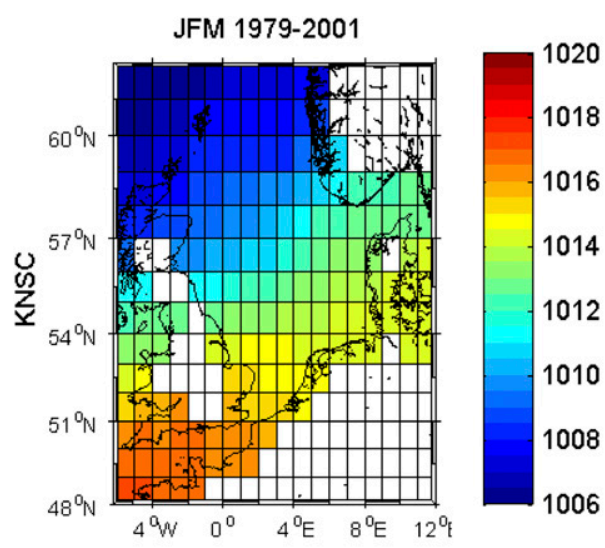

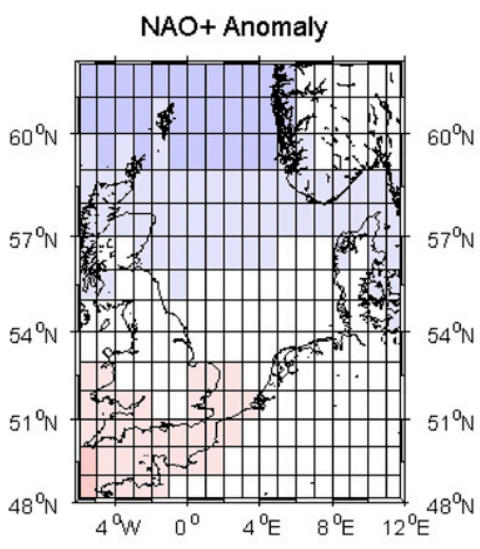
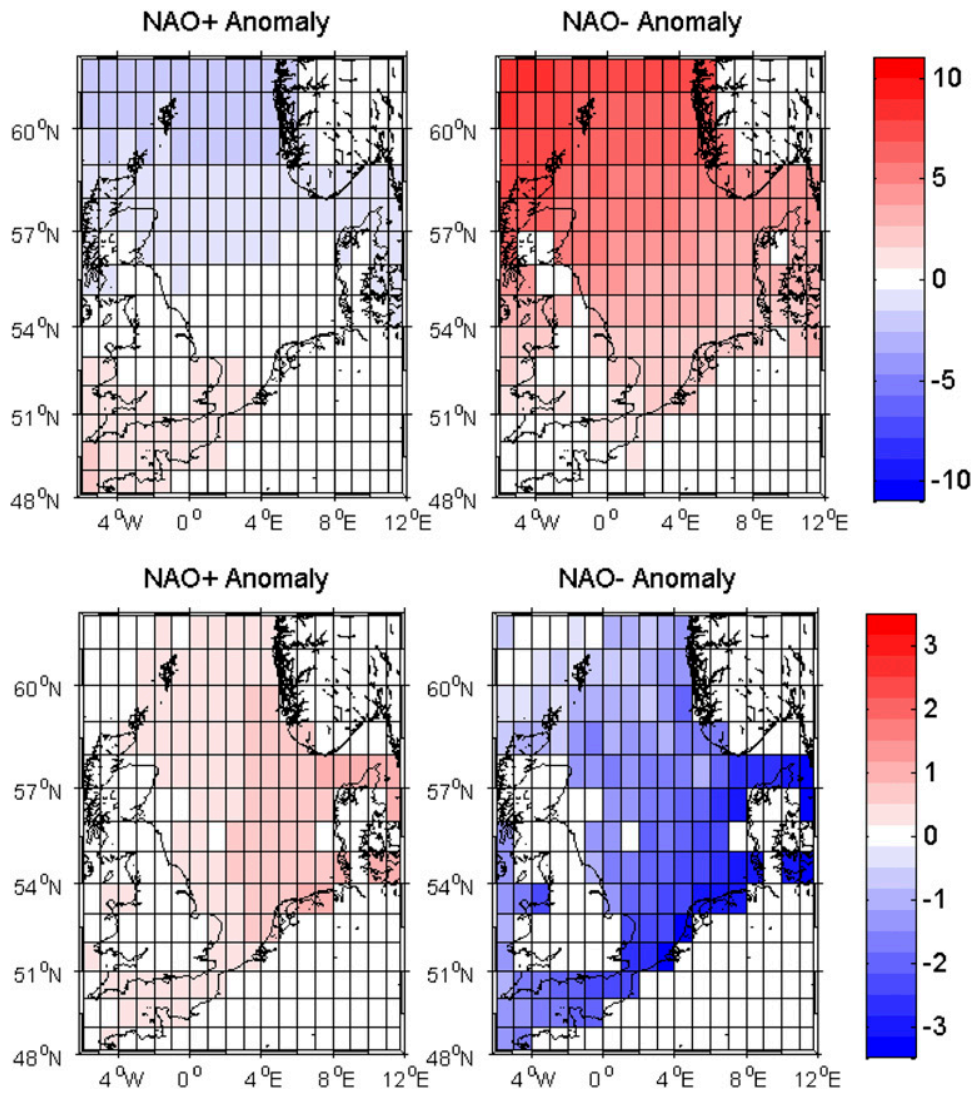

$\mathrm{NAO}+$ Anomaly

NAO- Anomaly
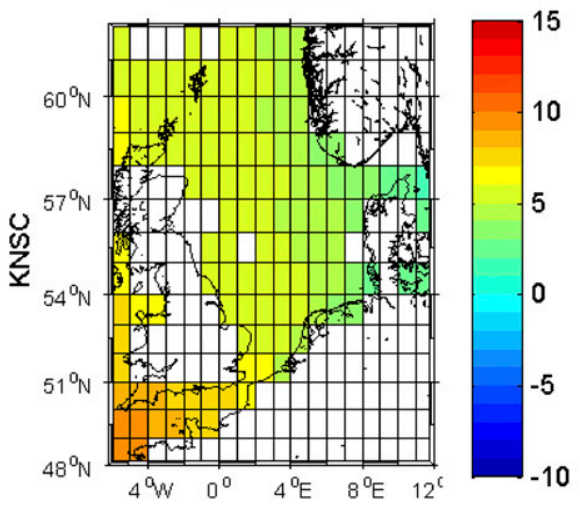

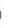



$-5$

10

FIG. 13. (left) Winter mean values of (top) KNSC SLP (hPa) and (bottom) 2-m AT $\left({ }^{\circ} \mathrm{C}\right)$ for the whole period 1979-2001, and the respective (middle) $\mathrm{NAO}+(\mathrm{hPa})$ and (right) $\mathrm{NAO}-(\mathrm{K})$ anomalies.

dominate not only the wintertime SLP pattern but also the annual mean in all reanalyses.

AT mean differences between ERA-40/ERA-Interim, MERRA, and KNSC can be found in coastal regions during both $\mathrm{NAO}+$ and NAO- years (Fig. 14, right three columns). The patterns are comparable to those in Figs. 4 and 6 . The cooling is slightly stronger during $\mathrm{NAO}-$, which indicates the influence of enhanced wintertime cooling over land, supporting the assumption that coastal AT differences are mainly driven by land effects. MERRA, NCEP-1, and 20CRv2 show slightly enhanced warming over the open North Sea during NAO - compared to KNSC.

\section{e. SLP and AT histograms}

Histograms of KNSC's monthly mean SLP and AT are presented in Fig. 15: SLP frequency distributions of the southern North Sea are slightly shifted toward higher values and are somewhat wider, but all peak at values of about $1015 \mathrm{hPa}$. The reanalysis's SLP distributions look similar in all subregions, but with the 20CRv2 distribution shifted toward higher values in general with less values up to $1015 \mathrm{hPa}$ and more values from $1015 \mathrm{hPa}$ on, compared to the other reanalyses and KNSC (Fig. 16). Again, the southeastern subregion displays pronounced differences of $15 \%$ less values around $1010 \mathrm{hPa}$ and $20 \%$ more values around $1020 \mathrm{hPa}$.

KNSC's AT distributions show the typical bimodal structure with maximum values between $6^{\circ}$ and $7^{\circ} \mathrm{C}$ and between $13^{\circ}$ and $15^{\circ} \mathrm{C}$ (Fig. 15). Both eastern subregions' distributions have wider tails and reduced peak values compared to their respective western subregions. MERRA and 20CRv2 again deviate most from KNSC, which is pronounced in the southeastern subregion (Fig. 17): Both distributions have wider tails and reduced peak values, that is, more extreme values that can be related to the coastal areas (colder in winter, warmer in summer). 20CRv2 also shows this behavior in the northeastern subregion, where especially the cold temperatures below $4^{\circ} \mathrm{C}$ are more frequent and temperatures between $5^{\circ}$ and $7^{\circ} \mathrm{C}$ are less frequent than in all other reanalyses (except NCEP-1) and KNSC. In general, temperatures between $4^{\circ}$ and $8^{\circ} \mathrm{C}$ and between $13^{\circ}$ and $20^{\circ} \mathrm{C}$ in the southeastern subregion show pronounced differences between all reanalyses and KNSC. 

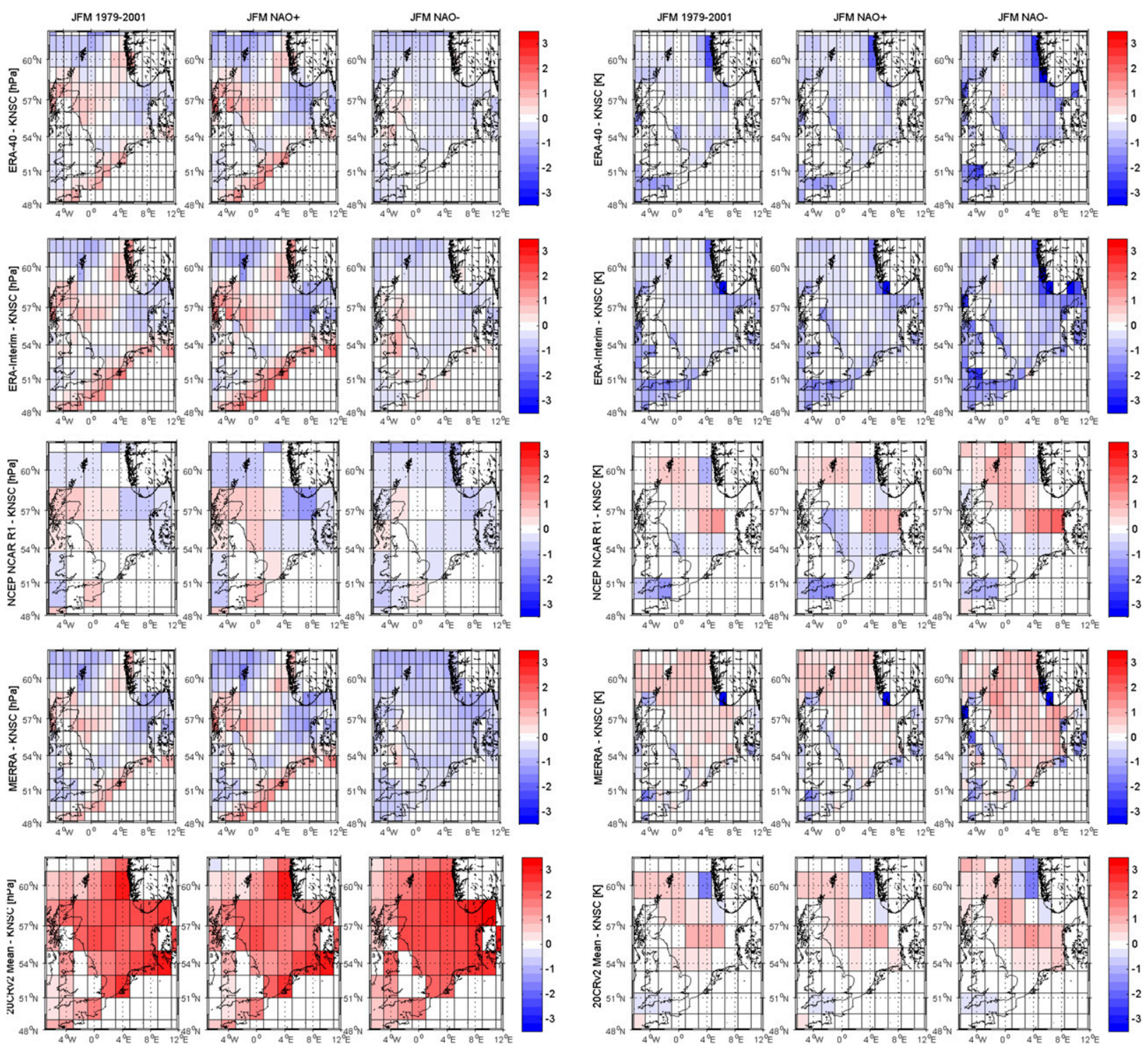

FIG. 14. Winter mean differences of (left three columns) SLP (hPa) and (right three columns) 2-m AT (K) between reanalyses and KNSC for the whole period 1979-2001 for the NAO+ and NAO- years (from top to bottom) for ERA-40, ERA-Interim, NCEP-1, MERRA, and 20CRv2 mean.

\section{Discussion}

The recently developed KNSC was used here to assess the quality of five global reanalyses on a regional scale, that is, the North Sea area. It has been found that relative to this new reference observational dataset, all atmospheric reanalyses show differences in SLP and 2-m AT fields that are most pronounced in coastal areas. These differences can be rationalized as the negative impact of coastal land stations on SLP and AT fields reaching far into the North Sea (Sadikni et al. 2018, their Fig. 12). MAEs are smaller than $0.3 \mathrm{hPa}$ in all combinations of KNSC, ERA-40, ERA-Interim, MERRA, and NCEP, and RMSEs are slightly higher and also change the overall ranking. For ATs, MAEs and RMSEs are up to 0.65 and $0.95 \mathrm{~K}$, respectively, while ERA-40/ERA-Interim and NCEP are about $0.5 \mathrm{~K}$ colder than KNSC in the mean. MERRA is slightly warmer than KNSC in almost all grid points, but the "cold spot" at the Norwegian coast levels the mean to an almost identical value. In this specific case, the presentation of MAE and RMSE in addition to the mean and the field mean plots showing regional differences (Fig. 4) is especially important for the evaluation. The mean value alone would suggest accordance within $0.06 \mathrm{~K}$, which de facto would not tell the whole story. 

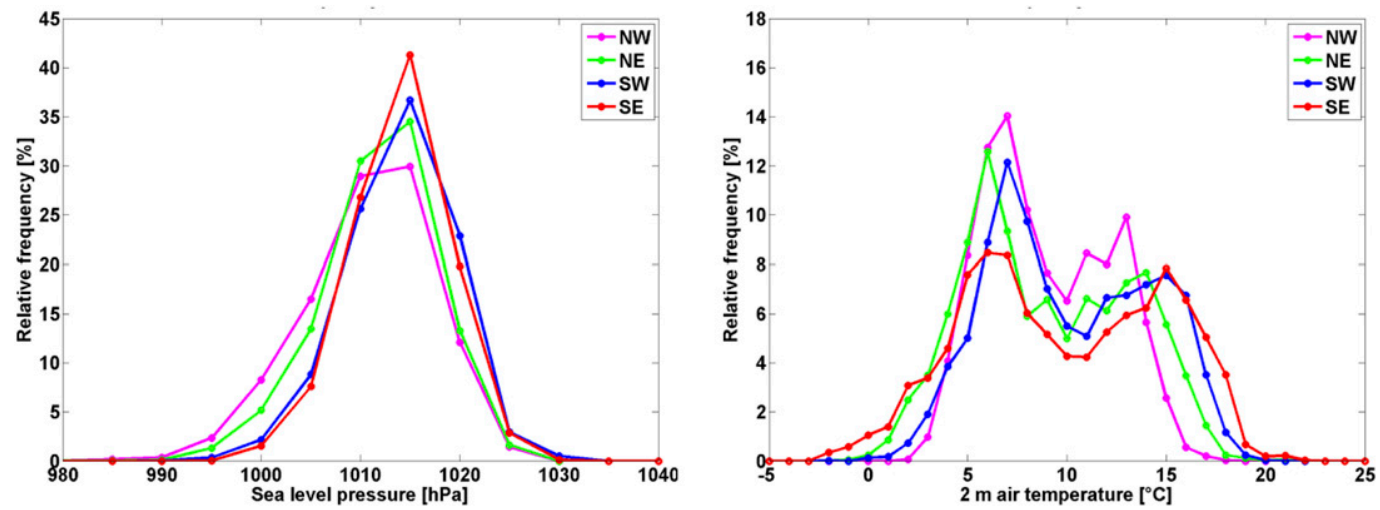

FIG. 15. Frequency distribution of monthly mean (left) SLP and (right) 2-m AT (\%) for KNSC in the four North Sea subregions (NW: magenta, NE: green, SW: blue, SE: red; see Fig. 1) for base period 1979-2001. Values for SLP are grouped in bins of $5 \mathrm{hPa}$ and values for $2-\mathrm{m} \mathrm{AT}$ in bins of $1^{\circ} \mathrm{C}$.

SLP difference patterns seem to be especially pronounced during $\mathrm{NAO}+$ phases as a result of enhanced pressure gradients, especially in coastal areas. In agreement with findings from, for example, Mooney et al. (2011), AT difference patterns show cooling effects in coastal regions for ERA-40/ERA-Interim and NCEP-1, especially during winter months. In contrast, coastal warming effects are evident in summer for MERRA and 20CRv2. Coastal biases are most pronounced in ERA-40 and ERA-Interim. MERRA does not properly represent the annual AT cycle in the southern parts of the North
Sea: winters are too cold and summers too warm. NCEP-1 agrees with KNSC for most parts within $\pm 1 \mathrm{hPa}$ $( \pm 1 \mathrm{~K})$. Interestingly, an overall improved agreement can be found toward the end of the investigated period in all reanalyses, presumably as a result of better data coverage rather than as a constraint.

We note that 20CRv2 stands as a negative exception revealing substantially larger biases: A nearly constant spatial and temporal SLP bias/offset to KNSC and all other reanalyses is apparent for the whole 56-member ensemble. It is expected that an ensemble will produce a
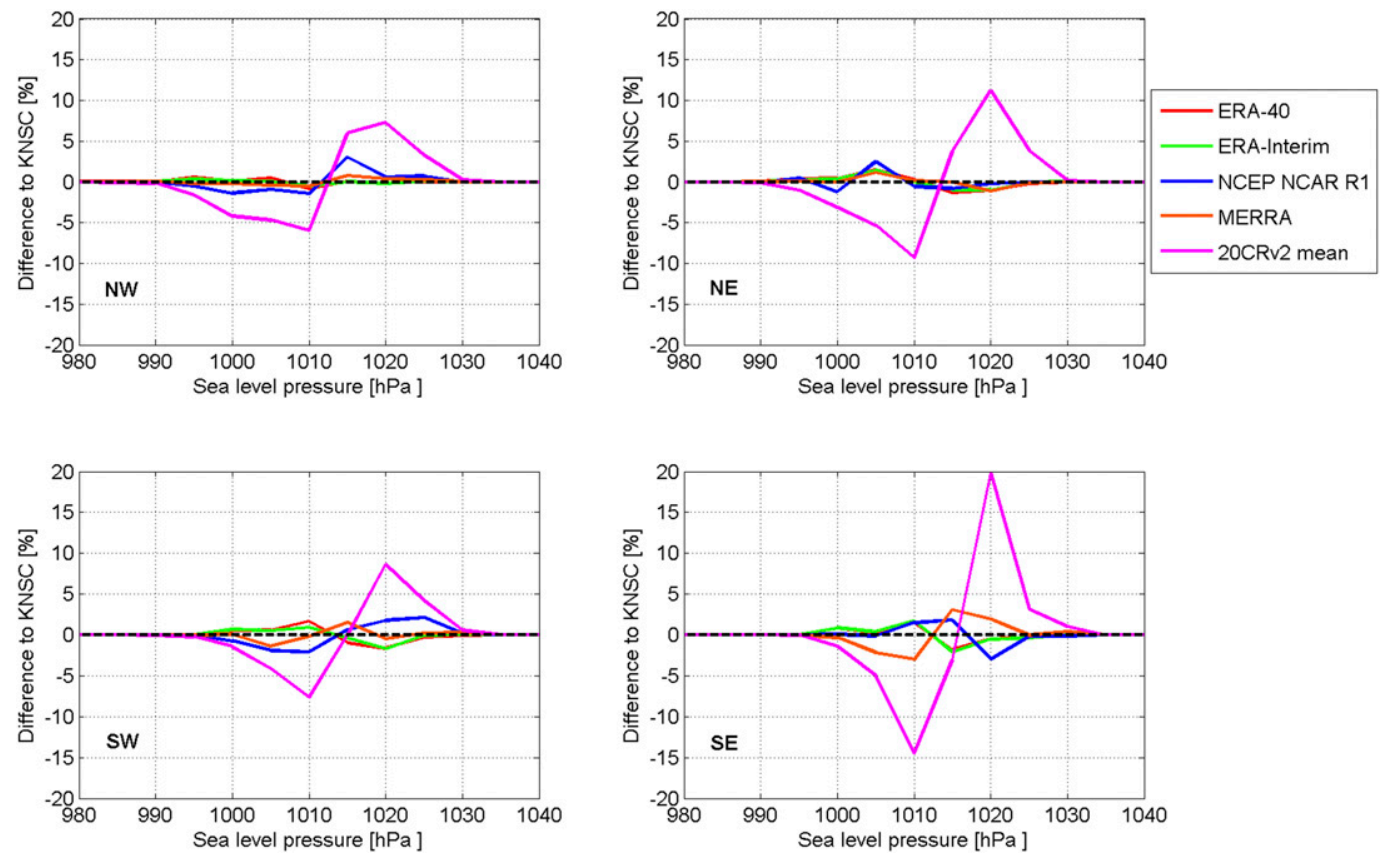

FIG. 16. Difference in the frequency distributions of monthly mean SLP (\%) between the five reanalyses and KNSC in the four North Sea subregions (NW, NE, SW, SE) for the base period 1979-2001.Values are grouped in bins of $5 \mathrm{hPa}$. 



FIG. 17. As in Fig. 16, but for 2-m AT (\%). Values are grouped in bins of $1^{\circ} \mathrm{C}$.

certain amount of spread; therefore, it is not surprising that some members follow a more extreme route. Nevertheless, the differences are significant and cannot be explained by random input errors alone. Compo et al. (2011) acknowledged problems with the sea ice treatment in the 20CR model, which introduces a warm bias in the Arctic in winter. A resulting effect on the pressure fields, which in return would have an impact on the North Sea pressure field as well, might be inherent, but it would not explain the SLP bias in the summer half year. Therefore, it might be a model bias as well, or a combination, which is supported by the fact that SLP means, MAEs, and RMSEs exceed the respective values between the other reanalyses and KNSC mentioned afore by far. 20CRv2 ATs also deviate from KNSC and the other reanalyses. The reasons are unclear, but they might be related to the pressure differences or the differences in the annual SLP cycle. The latter is supported by the fact that MERRA follows 20CRv2's annual AT and SLP cycles in the southern North Sea (see Fig. 9) despite its SLP results being much closer to ERA-40/ ERA-Interim, NCEP, and KNSC.

The differences between MAEs and RMSEs for both SLP and AT are relatively small; only some slight differences in the ranking can be found. Since 20CRv2 deviates from KNSC and the other reanalyses the most in almost all cases and the overall result is not changed, none of the error measures seems to be preferable in this case.

\section{Concluding remarks}

Because existing reanalyses remain to be performed with relatively low spatial resolution, differences to regional reference KNSC shown here for the North Sea had to be expected considering observational errors, inhomogeneities, and model biases. Nevertheless, they can be assumed to be typical, especially for coastal regions. However, 20CRv2 has to be considered as clearly unsatisfactorily - at least in the study area but presumably also elsewhere.

Since ERA-Interim and ERA-40 show almost identical results in all mean fields, annual cycles, and time series, it can be concluded that the upgrades in ERA-Interim did not change the overall performance of the model regarding the investigated parameters in the North Sea area. Aside from the slightly different intensity in coastal effects, no apparent advantages/ disadvantages have been found in this study in using the one or the other. Of course, this might be different in other regions of the world or in an analyses with a different focus, for example, climatic extremes and changes thereof.

We noted that both ERA-40's and ERA-Interim's land-sea masks contain a land fraction on coastal grid cells, given by values between 0 and 1 . Exclusion of all land-influenced grid cells would remove the coastal areas (land fraction between 0 and 0.2 ) from the analysis, resulting in a pronounced impact on the annual 
cycles of both AT and SLP. The land-sea masks of the other reanalyses do not differentiate between landinfluenced grid cells and the open sea. Further, ERA40 also shows colder temperatures in coastal areas when compared to the ENSEMBLES RCMs (Buelow et al. 2013), especially during winter months. All these RCMs have a horizontal resolution of $25 \mathrm{~km}$, which is about 5 times the resolution of ERA-40. This leads to the conclusion that the land influence is the dominating factor for the coastal cold bias, since it is mainly influenced by the model resolution and the interpolation on the output grids.

Addressing these coastal biases in atmospheric reanalyses is important for regional research activities and impact and climate risk studies. They may also be helpful in developing new reanalysis products that aim at representing the regional climate. It is expected that coastal biases, as presented in this work, will be greatly reduced by enhanced resolution alone. Also, the inclusion of satellite data to fill the gaps and to provide more homogeneous fields is desirable. The inclusion of existing and upcoming regional reanalyses (e.g., Luhamaa et al. 2011; Bollmeyer et al. 2015) and NCEP's coupled global atmosphere-ocean Climate Forecast System Reanalysis (CFSR; Saha et al. 2010) in future work would be the next step to address the effects of coupling and enhanced resolution in reanalyses systems.

Acknowledgments. Thanks go to the KLIWAS Sea and ICDC teams for the fruitful discussions and continuous support. The authors thank ECMWF for producing the ERA-40/ERA-Interim data and the WDCC for making them available for research. NCEP-1 is provided by the NOAA/OAR/ESRL/PSD, Boulder, Colorado, from its website (http://www.esrl.noaa.gov/ psd). MERRA data are part of the activities of NASA's Science Mission Directorate, and are archived and distributed by the Goddard Earth Sciences (GES) Data and Information Services Center (DISC). Support for the Twentieth Century Reanalysis (20CR) dataset is provided by the U.S. Department of Energy's Office of Science Innovative and Novel Computational Impact on Theory and Experiment (DOE INCITE) program and the Office of Biological and Environmental Research (NER), and by the National Oceanic and Atmospheric Administration (NOAA) Climate Program Office. The work presented here was conducted as part of the KLIWAS project of the German Federal Ministry of Transport and Digital Infrastructure (BMVI) and the Excellence Initiative CLISAP at the Universität Hamburg, funded through the German Science Foundation (Grant EXC 177/2).

\section{REFERENCES}

Barnston, A. G., and R. E. Livezey, 1987: Classification, seasonality and persistence of low-frequency atmospheric circulation patterns. Mon. Wea. Rev., 115, 1083-1162, https://doi.org/ 10.1175/1520-0493(1987)115<1083:CSAPOL >2.0.CO;2.

Beaugrand, G., 2004: The North Sea regime shift: Evidence, causes, mechanisms and consequences. Prog. Oceanogr., 60, 245-262, https://doi.org/10.1016/j.pocean.2004.02.018.

Bedacht, E., S. K. Gulev, and A. Macke, 2007: Intercomparison of global cloud cover fields over oceans from the VOS observations and NCEP/NCAR reanalysis. Int. J. Climatol., 27, 17071719, https://doi.org/10.1002/joc.1490.

Berrisford, P., D. P. Dee, K. Fielding, M. Fuentes, P. Kållberg, S. Kobayashi, and S. Uppala, 2009: The ERA-Interim archive. ECMWF ERA Rep. Series 1, 16 pp.

Bersch, M., V. Gouretski, R. Sadikni, and I. Hinrichs, 2013: KLIWAS North Sea climatology of hydrographic data (version 1.0). DKRZ World Data Center for Climate, accessed 11 January 2018, https://doi.org/10.1594/WDCC/KNSC_hyd_v1.0.

Betts, A. K., J. H. Ball, and P. Viterbo, 2003: Evaluation of the ERA-40 surface water budget and surface temperature for the Mackenzie River basin. ERA-40 Project Rep. Series 6, 33 pp. https://www.ecmwf.int/sites/default/files/elibrary/2003/8216evaluation-era-40-surface-water-budget-and-suface-temperaturemackenzie-river-basin.pdf.

BMVI, 2016: KLIWAS: Impacts of climate change on waterways and navigation in Germany; Concluding report of the BMVI: Technical conclusions from the results of the KLIWAS research programme. Federal Ministry of Transport and Digital Infrastructure, 111 pp., http://www.kliwas.de/KLIWAS/EN/ Service/Downloads/publications/concluding_report.html? $\mathrm{nn}=186428$.

Bollmeyer, C., and Coauthors, 2015: Towards a high-resolution regional reanalysis for the European CORDEX domain. Quart. J. Roy. Meteor. Soc., 141, 1-15, https://doi.org/10.1002/qj.2486.

Bosilovich, M. G., J. Chen, F. R. Robertson, and R. F. Adler, 2008: Evaluation of global precipitation in reanalyses. J. Appl. Meteor. Climatol., 47, 2279-2299, https://doi.org/10.1175/ 2008JAMC1921.1.

Buelow, K., and Coauthors, 2013: Comparing meteorological fields of the ENSEMBLES regional climate models with ERA-40 data over the North Sea. KLIWAS Schriftenreihe KLIWAS-21/2013, 133 pp., https://doi.org/10.5675/KLIWAS_21.2013_ERA40data.

Compo, G. P., and Coauthors, 2011: The Twentieth Century Reanalysis Project. Quart. J. Roy. Meteor. Soc., 137, 1-28, https:// doi.org/10.1002/qj.776.

Cram, T. A., and Coauthors, 2015: The International Surface Pressure Databank version 2. Geosci. Data J., 2, 31-46, https:// doi.org/10.1002/gdj3.25.

Davis, G., 2007: History of the NOAA satellite program. Appl. Remote Sens. J., 1, 012504, https://doi.org/10.1117/1.2642347.

Dee, D. P., and Coauthors, 2011: The ERA-Interim reanalysis: Configuration and performance of the data assimilation system. Quart. J. Roy. Meteor. Soc., 137, 553-597, https://doi.org/ 10.1002/qj.828.

Ferguson, C., and G. Villarini, 2012: Detecting inhomogeneities in the Twentieth Century Reanalysis over the central United States. J. Geophys. Res., 117, D05123, https://doi.org/10.1029/ 2011JD016988.

Francis, J. A., and S. J. Vavrus, 2012: Evidence linking Arctic amplification to extreme weather in mid-latitudes. Geophys. Res. Lett., 39, L06801, https://doi.org/10.1029/2012GL051000. 
Freeman, E., and Coauthors, 2017: ICOADS Release 3.0: A major update to the historical marine climate record. Int. J. Climatol., 37, 2211-2232, https://doi.org/10.1002/joc.4775.

John, V. O., and B. J. Soden, 2007: Temperature and humidity biases in global climate models and their impact on climate feedbacks. Geophys. Res. Lett., 34, L18704, https://doi.org/ 10.1029/2007GL030429.

Kalnay, E., and Coauthors, 1996: The NCEP/NCAR 40-Year Reanalysis Project. Bull. Amer. Meteor. Soc., 77, 437-471, https:// doi.org/10.1175/1520-0477(1996)077<0437:TNYRP>2.0.CO;2.

Kaspar, F., B. Tinz, H. Mächel, and L. Gates, 2015: Data rescue of national and international meteorological observations at Deutscher Wetterdienst. Adv. Sci. Res., 12, 57-61, https:// doi.org/10.5194/asr-12-57-2015.

Kent, E. C., and D. I. Berry, 2005: Quantifying random measurement errors in voluntary observing ship's meteorological observations. Int. J. Climatol., 25, 843-856, https://doi.org/ 10.1002/joc.1167.

Kistler, R., and Coauthors, 2001: The NCEP-NCAR 50-Year Reanalysis: Monthly means CD-ROM and documentation. Bull. Amer. Meteor. Soc., 82, 247-267, https://doi.org/10.1175/ 1520-0477(2001)082<0247:TNNYRM >2.3.CO;2.

Lindsay, R., M. Wensnahan, A. Schweiger, and J. Yhang, 2014: Evaluation of seven different atmospheric reanalysis products in the Arctic. J. Climate, 27, 2588-2606, https://doi.org/ 10.1175/JCLI-D-13-00014.1.

Loewe, P., Ed., 2009: System Nordsee: Zustand 2005 im Kontext langzeitlicher Entwicklungen. Bundesamt für Seeschifffahrt und Hydrographie Berichte des BSH 44, 261 pp., http://www.bsh.de/ de/Produkte/Buecher/Berichte_/Bericht44/index.jsp.

Lorenc, A. C., 1986: Analysis methods for numerical weather prediction. Quart. J. Roy. Meteor. Soc., 112,1177-1194, https:// doi.org/10.1002/qj.49711247414.

Luhamaa, A., K. Kimmel, A. Maennik, and R. Room, 2011: High resolution re-analysis for the Baltic Sea region during 19652005 period. Climate Dyn., 36, 727-738, https://doi.org/ 10.1007/s00382-010-0842-y.

McVicar, T. R., T. G. Van Niel, L. T. Li, M. L. Roderick, D. P. Rayner, L. Ricciardulli, and R. J. Donohue, 2008: Wind speed climatology and trends for Australia, 1975-2006: Capturing the stilling phenomenon and comparison with near-surface reanalysis output. Geophys. Res. Lett., 35, L20403, https://doi.org/10.1029/2008GL035627.

Mooney, P. A., F. J. Mulligan, and R. Fealy, 2011: Comparison of ERA-40, ERA-Interim and NCEP/NCAR reanalysis data with observed surface air temperatures over Ireland Int. J. Climatol., 31, 545-557, https://doi.org/10.1002/ joc. 2098.

Pawson, S., and M. Fiorino, 1999: A comparison of reanalyses in the tropical stratosphere. Part 3: Inclusion of the pre-satellite data era. Climate Dyn., 15, 241-250, https://doi.org/10.1007/ s003820050279.

Rayner, N. A., D. E. Parker, E. B. Horton, C. K. Folland, L. V. Alexander, and D. P. Rowell, 2003: Global analyses of sea surface temperature, sea ice, and night marine air temperature since the late nineteenth century. J. Geophys. Res., 108, 4407, https://doi.org/10.1029/2002JD002670.

Rienecker, M. M., and Coauthors, 2011: MERRA: NASA's Modern-Era Retrospective analysis for Research and Applications. J. Climate, 24, 3624-3648, https://doi.org/10.1175/ JCLI-D-11-00015.1.

Sadikni, R., M. Bersch, A. Jahnke-Bornemann, and I. Hinrichs, 2013: KLIWAS North Sea climatology of meteorological data (version 1.0). DKRZ World Data Center for Climate, accessed 11 January 2018, https://doi.org/10.1594/WDCC/ KNSC_met_v1.0.

, N. H. Schade, A. Jahnke-Bornemann, I. Hinrichs, L. Gates, B. Tinz, and D. Stammer, 2018: The KLIWAS North Sea climatology. Part I: Processing of the atmospheric data. J. Atmos. Oceanic Technol., https://doi.org/ 10.1175/JTECH-D-17-0044.1, 111-126.

Saha, S., and Coauthors, 2010: The NCEP Climate Forecast System Reanalysis. Bull. Amer. Meteor. Soc., 91, 1015-1057, https:// doi.org/10.1175/2010BAMS3001.1.

Schade, N. H., H. Heinrich, and G. Rosenhagen, 2013: Regional evaluation of ERA-40 reanalysis data with marine atmospheric observations in the North Sea area. Meteor. Z., 22, 675-684, https://doi.org/10.1127/0941-2948/ 2013/0471.

Screen, J. A., and I. Simmonds, 2011: Erroneous arctic temperature trends in the ERA-40 reanalysis: A closer look. J. Climate, 24, 2620-2627, https://doi.org/10.1175/2010JCLI4054.1.

Simmons, A. J., and Coauthors, 2004: Comparison of trends and low-frequency variability in CRU, ERA-40, and NCEP/ NCAR analyses of surface air temperature. J. Geophys. Res., 109, 675-684, https://doi.org/10.1029/2004JD005306.

Sterl, A., 2004: On the (in) homogeneity of reanalysis products. J. Climate, 17, 3866-3873, https://doi.org/10.1175/1520-0442 (2004)017<3866:OTIORP $>2.0$. CO;2.

Thorne, P. W., and R. S. Vose, 2010: Reanalyses suitable for characterizing long-term trends. Bull. Amer. Meteor. Soc., 91, 353-361, https://doi.org/10.1175/2009BAMS2858.1.

Uppala, S. M., and Coauthors, 2005: The ERA-40 Re-Analysis. Quart. J. Roy. Meteor. Soc., 131, 2961-3012, https://doi.org/ 10.1256/qj.04.176.

Watanabe, M., and T. Nitta, 1999: Decadal changes in the atmospheric circulation and associated surface climate variations in the Northern Hemisphere winter. J. Climate, 12, 494-510, https://doi.org/10.1175/1520-0442(1999)012<0494: DCITAC $>2.0 . \mathrm{CO} ; 2$.

WCRP, 2012: Report of the 4th World Climate Research Programme International Conference on Reanalyses. WCRP Rep. 12/2012, 41 pp., http://www.wcrp-climate.org/documents/ ICR4_Report.pdf.

Whitaker, J. S., and T. M. Hamill, 2002: Ensemble data assimilation without perturbed observations. Mon. Wea. Rev., 130, 1913-1924, https:// doi.org/10.1175/1520-0493(2002)130<1913:EDAWPO>2.0.CO;2.

WMO, 1988: General meteorological standards and recommended practices. Vol. I, Technical regulations, Basic Doc. 2, WMO49, 82 pp., http://www.wmo.int/pages/prog/hwrp/publications/ technical_regulations/WMO_N49_TechnReg_Vol1.pdf.

1994: International list of selected, supplementary and auxiliary ships. WMO-47, https://www.wmo.int/pages/prog/www/ ois/pub47/pub47-home.htm.

2015: Manual on the Global Telecommunication System: Annex III to the WMO technical regulations. WMO386, 214 pp. [Available online at https://library.wmo.int/ opac/doc_num.php? explnum_id $=3678$.

Woodruff, S. D., and Coauthors, 2011: ICOADS Release 2.5: Extensions and enhancements to the surface marine meteorological archive. Int. J. Climatol., 31, 951-967, https://doi.org/ 10.1002/joc.2103.

Worley, S. J., S. D. Woodruff, R. W. Reynolds, S. J. Lubker, and N. Lott, 2005: ICOADS release 2.1 data and products. Int. J. Climatol., 25, 823-842, https://doi.org/10.1002/ joc.1166. 